JOURNAL OF ENVIRONMENTAL QUALITY

\title{
Dynamics of measured and simulated dissolved phosphorus in runoff from winter-applied dairy manure
}

\begin{tabular}{|c|c|}
\hline Journal: & Journal of Environmental Quality \\
\hline Manuscript ID & JEQ-2018-11-0416-AWG.R2 \\
\hline Manuscript Type: & Special Section: Agricultural Water Quality under Cold Conditions \\
\hline Technical Report Subtypes: & Surface Water Quality \\
\hline $\begin{array}{r}\text { Date Submitted by the } \\
\text { Author: }\end{array}$ & 12-Apr-2019 \\
\hline Complete List of Authors: & $\begin{array}{l}\text { vadas, peter; USDA-ARS-DFRC } \\
\text { Stock, Melanie; Utah Valley University, Plants, Soils, \& Climate } \\
\text { Arriaga, Francisco; University of Wisconsin, Deptartment of Soil Science } \\
\text { Good, Laura; University of wisconsin-Madison, Soil Science } \\
\text { Karthikeyan, K.G.; University of Wisconsin } \\
\text { Zopp, Zachariah; University of Wisconsin-Madison, Biological Systems } \\
\text { Engineering }\end{array}$ \\
\hline Keywords: & winter, runoff, dairy manure \\
\hline
\end{tabular}

\section{SCHOLARONE \\ Manuscripts}




\title{
Dynamics of measured and simulated dissolved phosphorus in runoff from winter-applied dairy manure
}

\author{
Peter A. Vadas ${ }^{a^{*}}$, Melanie N. Stock ${ }^{b}$, Francisco J. Arriagac, Laura W. Good , K.G. \\ Karthikeyan $^{d}$ and Zachariah P. Zopp ${ }^{d}$
}

aP.A. Vadas, USDA-ARS, U.S. Dairy Forage Research Center, 1925 Linden Dr., Madison, WI 53706

${ }^{\mathrm{b} M . N . ~ S t o c k . ~ U t a h ~ S t a t e ~ U n i v e r s i t y, ~ D e p a r t m e n t ~ o f ~ P l a n t s, ~ S o i l s, ~ \& ~ C l i m a t e, ~} 4820$ Old Main Hill, Logan, UT 84322-4820

cF.J. Arriaga, L.W. Good. University of Wisconsin-Madison, Department of Soil Science, 1525 Observatory Drive Madison, WI 53706

${ }^{\mathrm{d}}$ K.G. Karthikeyan, Z.P. Zopp. University of Wisconsin-Madison, Department of Biological Systems Engineering, 460 Henry Mall, Madison, WI 53706

*Corresponding author: Peter A. Vadas, peter.vadas@ars.usda.gov 

Abstract

7

Agricultural phosphorus (P) loss from fields is an issue due to water quality degradation. Better information is needed on the P loss in runoff from dairy manure applied in winter and the ability to reliably simulate $\mathrm{P}$ loss by computer models. We monitored $\mathrm{P}$ in runoff during two winters from CT and NT field plots that had liquid dairy manure applied in December or January. Runoff total $\mathrm{P}$ was dominated by non-dissolved forms when soils were bare and unfrozen. Runoff from snow-covered, frozen soils had much less sediment and sediment-related $\mathrm{P}$, and much more dissolved P. Transport of manure solids was greatest when manure was applied on top of snow and runoff shortly after application was caused by snowmelt. Dissolved P concentrations in runoff were greater when manure was applied on top of snow because manure liquid remained in the snowpack and allowed more $\mathrm{P}$ to be available for loss. Dissolved runoff $\mathrm{P}$ also increased as the amount of rain or snowmelt that became runoff (runoff ratio) increased. SurPhos reliably simulated these processes to provide realistic predictions of dissolved $\mathrm{P}$ in runoff. Overall for liquid dairy manure applied in winter, dissolved $\mathrm{P}$ concentrations in runoff can be decreased if manure is applied onto bare, unfrozen soil, or if runoff ratio can be reduced, perhaps through greater soil surface roughness from fall tillage. Both management approaches will allow more manure P to infiltrate into soil and less move in runoff. SurPhos is a tool that can reliably evaluate P loss for different management and policy scenarios for winter manure application. 
Agricultural nutrient management is a research and policy issue due in part to $\mathrm{P}$ loss in runoff and subsequent water quality degradation (Parris, 2011; Sharpley, 2016). Manure applied to fields without incorporation is an important source of P loss (Good et al., 2012), especially dissolved $\mathrm{P}$ that has high bioavailability in aquatic systems (Baker et al., 2014). For surfaceapplied manure, maximum dissolved $\mathrm{P}$ loss occurs when manure with highly available $\mathrm{P}$ is applied during times of high runoff probability (Vadas et al., 2017; Owens et al., 2011). In the northern U.S. and Canada, winter and early spring are periods of frequent runoff from snowmelt and rain-on-snow events on frozen soils. In some states, winter dairy manure application is common because it reduces the need for manure storage, allows time for spreading when there are fewer field activities, and reduces soil compaction from equipment when soil is frozen (Lewis and Makarewicz, 2009; Liu et al., 2017). Because winter-applied manure is typically not incorporated, the combination of surface manure and high runoff potential has prompted states to restrict winter spreading (Liu et al., 2018; Srinivasan et al., 2006).

Processes controlling manure dissolved P runoff during winter vary widely depending on P cycling, weather, frozen soil conditions, runoff hydrology, as well as manure spreading practices, especially placement on top of snow and the effect of manure on rates of snowmelt (Kongoli and Bland, 2002; Vadas et al., 2018; Stock et al., 2019). Studies that investigate and report the biochemical and hydrologic processes that control dissolved $\mathrm{P}$ runoff concentrations transport after manure application are limited. Most studies have been observational at the plot to field scale with conflicting results regarding how much winter manure application increases $\mathrm{P}$ runoff relative to other seasons, often because of annually variable weather, frozen soil conditions, and runoff hydrology. Much research was conducted before 1980 (Converse et al., 1976; Klausner et al., 1976; Steenhuis et al., 1981; Young and Holt, 1977; Phillips et al., 1981; 
Young and Mutchler, 1976), with some more recently (Lewis and Makarewicz, 2009; Owens et al., 2011; Hansen et al., 2000; Komiskey et al., 2011; Ulen, 2003; Singh et al., 2017). Recent research (Williams et al., 2012b, a; Williams et al., 2011; Vadas et al., 2018) has investigated winter processes and manure $\mathrm{P}$ loss at the controlled lab scale, but there remains a definite lack of similarly focused data from field studies under natural conditions. This makes it difficult to develop scientifically-based winter manure application recommendations that can consistently reduce $\mathrm{P}$ loss for a variety of conditions and practices.

Research reported here is part of a series of experiments designed to improve understanding and modeling of processes controlling runoff and nutrient loss from winter-applied manure (Vadas et al., 2017; Vadas et al., 2018; Stock et al., 2019). Our objectives were to i) describe how manure application timing and runoff hydrology control dissolved $\mathrm{P}$ concentrations in runoff from field plots receiving liquid dairy manure, and ii) determine if the SurPhos model (Vadas et al., 2007) can reliably simulate dissolved $\mathrm{P}$ concentrations in runoff for the experimental winter conditions. Stock et al. (this issue) describe the approach used in the field study and the effects of application timing and tillage on nutrient runoff loads $\left(\mathrm{kg} \mathrm{ha}^{-1}\right)$. This paper focuses on dissolved $\mathrm{P}$ runoff concentrations to better understand and model $\mathrm{P}$ runoff dynamics as a function of source (P available in manure) and hydrology (both the rain and snowmelt water that mobilizes available manure $\mathrm{P}$ and the percent of that water becomes runoff). Throughout, the term "runoff ratio" refers to the ratio of runoff water to the total water that interacted with manure, including rain, snowmelt, or both. Finally, Vadas et al. (2017) successfully used SurPhos to simulate winter manure P in runoff for data from two WI field studies. In one study, manure was never applied onto snow; and the second study was on a commercial farm were there was uncertainty about manure application rates and $\mathrm{P}$ contents. For the second study, the authors also had to make assumptions about liquid 
108

109

110

\section{Materials and Methods}

112

manure P availability when applied on top of snow to improve model predictions. Our current evaluation provided an opportunity to test SurPhos using more controlled field data.

\section{Field Site Description and Measurements}

The site was at the University of Wisconsin - Madison Arlington Agricultural Research Station (AARS; $43^{\circ} 17^{\prime} \mathrm{N} 89^{\circ} 21^{\prime} \mathrm{W}$ ). Study details are given by Stock et al. (this issue) and only briefly described here. There were 18 plots ( 5 wide x $15 \mathrm{~m}$ long each) with two tillage and three manure timing treatments in a complete factorial design on a $5.8 \%$, south-facing slope with silt-loam texture. During the study (2015-2017), plots were cropped in corn for silage with field operations performed perpendicular to the downhill $15-\mathrm{m}$ plot length. Tillage treatments were fall chisel tillage (CT) with a soil finisher pass in the spring, and NT (NT), and resulted in rough and smooth soil surfaces during the winter. Manure treatments were early-December application, late-January application, and unmanured control. All treatment combinations had three replications. We applied liquid dairy manure (2-6\% solids) at $37.4 \mathrm{~kL} \mathrm{ha}^{-1}$, which was a function of local regulations, and analyzed manure for total solids and total P (University of Wisconsin Soil and Forage Analysis Laboratory) (see Stock et al., this issue for data). Manure TP application rate ranged from 8.7 to $11.3 \mathrm{~kg} \mathrm{ha}^{-1}$ the first winter, and 14.4 to $17.8 \mathrm{~kg} \mathrm{ha}^{-1}$ the second winter. For SurPhos modelling, we assumed manure water extractable $\mathrm{P}$ (WEP) was $50 \%$ of total $\mathrm{P}$ (Kleinman et al., 2005).

An on-site weather station measured air temperature and precipitation as rain or liquid equivalent of snow. We measured ground snow depth and density on plots to estimate snow-water equivalent (SWE) at least weekly and up to daily during precipitation and thaw events. A collection system that used a series of buckets with water-dividing crown heads measured runoff from each 
131 plot (Bonilla et al., 2006; Vadas and Powell, 2013). We collected water samples at the end of each

132 runoff event and stored them at $4^{\circ} \mathrm{C}$ until analysis. We measured runoff solids content

133 gravimetrically after oven drying samples, analyzed unfiltered samples for total P colorimetrically

134 after Kjeldahl digestion (AQ2 Discrete Analyzer, SEAL Analytical Brand, Mequon, WI) and

135 filtered runoff samples $(0.45 \mu \mathrm{m})$ for dissolved reactive P colorimetrically (Murphy and Riley,

136 1962). All runoff hydrology and $P$ concentrations data presented in the paper for specific runoff

137 events are means of the plot replications that actually produced runoff. For 39 events, 36 had runoff

138 from all three replicates, and only 3 had runoff from 2 replicates.

139

140

141

142

143

144

145

146

147

148

149

150

151

152

153

\section{SurPhos Modelling}

SurPhos is a daily time-step model that simulates surface application of manure and dissolved P loss in runoff, as well as soil P cycling. Because SurPhos was designed to be integrated into larger field or watershed models to improve how they simulate agricultural P cycling (Collick et al., 2016; Liu et al., 2017; Sedorovich et al., 2007), it does not simulate all processes that affect $\mathrm{P}$ loss in runoff namely crop growth, runoff, or soil erosion and particulate $\mathrm{P}$ loss. SurPhos requires input data for initial soil P content, amount of manure applied, moisture and $\mathrm{P}$ content of manure, daily average temperature, and daily precipitation and runoff. Experimental data from the field study provided all the necessary inputs.

SurPhos simulates both water extractable (WEP) and non-water extractable P (Non-WEP). Only WEP is available for release during a rain or snowmelt event and loss in runoff. SurPhos also simulates inorganic soil P cycling and dissolved loss in runoff. Users specify the day and rate of manure application, manure $\mathrm{P}$ content, and application method. If liquid manure $(<15 \%$ solids $)$ is applied, SurPhos assumes $60 \%$ of manure $\mathrm{P}$ infiltrates into soil and is unavailable for direct loss 
154 in runoff. After application, the model simulates manure decomposition and assimilation into soil,

155

156

157

158

159

160

161

162

163

164

165

166

167

168

169

170

171

172

173

174

175

176 and conversion of Non-WEP into WEP. When rain or snowmelt occurs, SurPhos simulates manure WEP release based on the ratio of water volume to manure mass $\left(\mathrm{cm}^{3} \mathrm{~g}^{-1}\right)$. Dissolved $\mathrm{P}$ in runoff is estimated by multiplying this released $\mathrm{P}$ by a unitless $\mathrm{P}$ Distribution Factor $\left(\mathrm{P}_{\mathrm{d}}\right)$, which is a function of the runoff ratio. Overall, SurPhos considers both manure properties and storm hydrology when estimating P loss in runoff, but it is largely the event hydrology, as represented by the amount of rain or snowmelt and the runoff ratio, that control both $\mathrm{P}$ concentrations and loads in runoff.

In SurPhos for rain-only events, the amount of water that can release manure WEP is measured precipitation. For snowmelt events, mobilizing water is the difference in SWE before and after an event (Vadas et al., 2017). In this project, we used measured snowfall to estimate inputs of available snow water onto plots, and estimated daily snowmelt using a degree-day method where the snowmelt rate was $2.5 \mathrm{~mm}^{\circ} \mathrm{C}^{-1}$ (mean daily air temperature) greater than 0.0 (USDA-NRCS, 2004). We estimated how much snowmelt, as well as any rain, was absorbed by snow before it became free-flowing water and interacted with manure. To do this, we assumed that the depth of fresh snow was 12 times the water equivalent depth and that snow could absorb water up to $6 \%$ of its depth. For example, if $100 \mathrm{~mm}$ of snow fell (actual snow depth), it could absorb 6 $\mathrm{mm}$ of water (either snowmelt or rain). If there were $3 \mathrm{~mm}$ of snowmelt (water equivalent) and 2 $\mathrm{mm}$ of rain, snow absorption capacity was reduced to $<1 \mathrm{~mm}$ (less snow would reduce absorption capacity as well as an increase in absorbed water), and remained there until more snowmelt or rain occurred to decrease absorption capacity or new snow fell to increase capacity. We used a daily amount of liquid water present that exceeded snow absorption capacity to simulate interaction with manure. Throughout this process, we adjusted estimated SWE data so they matched measured 
177 SWE data. For example, if decreases in measured SWE occurred during days of freezing

178

179

180

181

182

183

184

185

186

187

188

189

190

191

192

193

194

195

196

197

temperatures, we assumed decreases were due to sublimation or snow drift (and not snowmelt) and decreased estimated SWE to match measured values and not overestimate snowmelt later on. Throughout, we did not consider manure placement in the snowpack as a variable that needed to be accounted for in modeling snowmelt water interaction with manure (Vadas et al., 2018).

We compared measured and simulated dissolved $\mathrm{P}$ concentrations in runoff for the two years of field data, using regression methods to evaluate model performance, including slope, intercepts, Nash-Sutcliffe model efficiency (NSE), root mean square error (RMSE), and the ratio of RMSE to the standard deviation of observed values (RSR) (Bennett et al., 2013; Moriasi et al., 2007; Bolster and Vadas, 2013). We evaluated if slopes relating measured and predicted values were different than 1.0, and if intercepts were different from $0.0(p=0.05)$. Nash-Sutcliffe efficiencies range from $-\infty$ to 1 . An efficiency of 1 means a perfect match of modeled and observed data, zero indicates model predictions are as accurate as the mean of observed data, and less than zero is when the observed mean is a better predictor than the model. The RMSE is a measure of the average difference between predicted and observed values. The RSR varies from an optimal value of 0 , which indicates zero RMSE and perfect model simulation, to a large positive value.

\section{Results and Discussion}

\section{Field Runoff Hydrology}

In 2015-2016 between early December and late March, there were a maximum of five runoff events after manure application from any treatment and a minimum of one (Table 1, Fig. 1). The CT plots generally had less runoff frequency and magnitude because rougher surface conditions created depressional storage that retained water (Table 1, Fig. 1) (see details in Stock et al., this issue). The early December and late March runoff events were due to rain on bare, 
unfrozen soil. Events in between these times were due to rain-on-snow and snowmelt-only events. In 2016-2017 between early December and late March, there were a maximum of nine runoff events from any treatment after manure application and a minimum of four (Table 1, Fig. 2). The NT plots still had greater runoff frequency and magnitude, but not to the extent as in $2015-2016$ (Table 1, Fig. 2). The majority of events were rain-on-snow events, with only the last event in late February due to rain on bare soil (Table 1, Fig. 2).

\section{Runoff Dissolved P Dynamics}

The December 10, 2015 manure application was on unfrozen, bare soil. After application there were five runoff events from NT plots and one from CT plots (Fig. 1, Table 1). The January 26, 2016 manure application was on top of snow, with soil frozen to $50 \mathrm{~cm}$. After this application, there were five runoff events from NT plots and one from CT plots (Fig. 1, Table 1). The December 9, 2016 application was on top of snow overlying soil frozen to $10 \mathrm{~cm}$, followed by nine runoff events from NT plots and four from CT plots (Fig. 2, Table 1). The January 27, 2017 application was on top of snow overlying soil that was thawed at the surface but frozen from $6-44 \mathrm{~cm}$. After application, there were four runoff events from NT plots and one from the CT plots (Fig. 2, Table 1). Snow depths at times of manure application ranged from 10 to $20 \mathrm{~cm}$ (Stock et al., 2019).

The two winters represented a wide range of runoff conditions from bare (no snow), unfrozen soil to snow-covered, frozen soil. For bare soils, including no-manure controls, total runoff $\mathrm{P}$ across 21 events (considering manure treatments, tillage treatments, and controls separately) was dominated by non-dissolved forms, with dissolved $\mathrm{P}$ accounting for only $9.5 \%$ (s.d. 9.4\%) of total P. In contrast across 42 events from snow-covered, frozen soils, dissolved P accounted for $67 \%$ (s.d. 21\%) of total runoff $\mathrm{P}$. This is in part a function of much less solids in 
224 runoff from frozen soil. Runoff solids from snow-covered, frozen soils ranged from 23 to 4,456

$225 \mathrm{mg} \mathrm{L}^{-1}$ (median of $339 \mathrm{mg} \mathrm{L}^{-1}$ ), and from bare soils ranged from 1,311 to $12,270 \mathrm{mg} \mathrm{L}^{-1}$ (median

226 of 2,176 $\left.\mathrm{mg} \mathrm{L}^{-1}\right)$. Given the importance of this dissolved $\mathrm{P}$ transport in winter runoff, the following

227 section details its dynamics.

For the 2015 December manure application, the greatest dissolved $\mathrm{P}$ in runoff $(0.95 \mathrm{mg}$ $\mathrm{L}^{-1}$, Fig. 3) was from NT plots in the first event after application, which occurred three days after application and was a rain event on bare, unfrozen soil (Fig. 1, Table 1). One reason for this relatively low runoff $\mathrm{P}$ concentration is because manure was applied to bare, unfrozen soil and had

232 a chance to infiltrate into soil at application, leaving less manure $\mathrm{P}$ on the surface available to runoff. SurPhos assumes that such liquid infiltration decreases manure $\mathrm{P}$ on the surface by $60 \%$

234 (Vadas, 2006). A second reason is that this runoff event had a low runoff ratio ( $\sim 1.6 \mathrm{~mm}$ of runoff compared to $49.6 \mathrm{~mm}$ of rain), meaning that most of the manure $\mathrm{P}$ mobilized by rain during the event infiltrated into soil rather than moving in runoff (Vadas et al., 2011). After this first event, runoff dissolved $\mathrm{P}$ from NT plots decreased to a steady concentration (average of $0.26 \mathrm{mg} \mathrm{L}^{-1}$ ) that was similar to control plot concentrations (average of $0.16 \mathrm{mg} \mathrm{L}^{-1}$ ). This decrease is due to declines in manure $\mathrm{P}$ content due to leaching of $\mathrm{P}$ out of manure over time by snowmelt and rain. The only runoff event from CT plots after the December application was on February 20, and runoff 241 dissolved $\mathrm{P}\left(0.13 \mathrm{mg} \mathrm{L}^{-1}\right)$ was similar to that from NT plots with the same manure application $242 \quad\left(0.26 \mathrm{mg} \mathrm{L}^{-1}\right)$ or control plots.

The 2016 January manure application had much greater $\left(\sim 4-5 \mathrm{mg} \mathrm{L}^{-1}\right)$ runoff dissolved $\mathrm{P}$ 244 from NT plots in the first events after application than the earlier December 2015 application (Fig. 2453 ). One reason is that the January application was on top of snow; thus the manure liquid remained 246 in the snowpack and increased the manure P available to runoff (Vadas et al., 2017; Vadas et al., 
2018). Another reason was that runoff ratios (Table 1) for events after the January manure application were much greater than for the first event after the December application. This meant relatively more manure $\mathrm{P}$ mobilized by rain and snowmelt moved in runoff. Runoff dissolved $\mathrm{P}$ from NT plots after the January manure application was high for three events before decreasing substantially for the last two events (Fig. 3). Conversely, for the one runoff event on February 18 from CT plots after the January application, runoff $\mathrm{P}\left(0.96 \mathrm{mg} \mathrm{L}^{-1}\right)$ was about four times less than that from NT plots $\left(4.36 \mathrm{mg} \mathrm{L}^{-1}\right)$. Assuming that manure P availability was similar for both $\mathrm{CT}$ and NT plots for this event, less runoff P from CT plots is most likely due to less runoff (3-5 mm compared to $40 \mathrm{~mm}$ for NT plots; Table 1) and a subsequently lower runoff ratio.

For the December 2016 manure application, dissolved P in the first runoff event from NT plots $\left(0.64 \mathrm{mg} \mathrm{L}^{-1}\right)$ was less than in the next three events $\left(\sim 3-5 \mathrm{mg} \mathrm{L}^{-1}\right)$ (Fig. 3). Thereafter, runoff dissolved $\mathrm{P}$ was much less (average of $0.47 \mathrm{mg} \mathrm{L}^{-1}$ ) and closer to control plot concentrations (average of $0.15 \mathrm{mg} \mathrm{L}^{-1}$ ) (Fig. 3). These trends are consistent with data from the previous year for high runoff $P$ in early events after application and decreased runoff $P$ in later events. However, the first event had the least runoff $\mathrm{P}$ of the first four events. This is likely due to a low runoff ratio for this event $(0.02, \sim 26 \mathrm{~mm}$ of rain and snowmelt water and $0.4 \mathrm{~mm}$ of runoff) compared to the next three events (runoff ratios of 0.45 to 0.84 ) (Table 1). It may also be due to a lower than typical rate of manure P release by snowmelt water compared to what we have observed for other manures in our research (see Vadas et al., 2018, and discussion about SurPhos modeling assumptions later in this paper). For the December 2016 application on CT plots, runoff did not occur until January 10, and runoff dissolved $\mathrm{P}$ for this and the next two events (average of $0.97 \mathrm{mg} \mathrm{L}^{-1}$ ) was three to four times less than runoff P from the NT plots for the same dates (Fig. 3). As we proposed for the 2016 January manure application, this is most likely due to less runoff from CT plots $(0.4-9 \mathrm{~mm}$ 
compared to 8-23 mm from NT plots; Table 1) and subsequently lower runoff ratios. Dissolved P in runoff was much less from both CT and NT plots after the end of January, reflecting reduced P availability in manure after two to three months of exposure to rain and snowmelt.

Overall, runoff $\mathrm{P}$ concentrations for the December manure application were much greater in 2016-2017 than in 2015-2016, most likely because the 2016-2017 application was on top of snow instead of onto bare, unfrozen soil. This allowed manure liquid to remain in the snowpack and leave more manure $\mathrm{P}$ available for loss in runoff. In fact, the greatest runoff $\mathrm{P}$ concentrations for the 2016 December manure application were similar to those for the 2016 January manure application, which was also applied on top of snow.

After the January 2017 manure application, dissolved P was relatively high in the first three runoff events from NT plots $\left(\sim 2-5 \mathrm{mg} \mathrm{L}^{-1}\right)$ before decreasing in the last event $\left(1.07 \mathrm{mg} \mathrm{L}^{-1}\right)$ (Fig. 3). For the January application on CT plots, runoff P in the only event (February 14, 2017) $(2.89$ $\mathrm{mg} \mathrm{L^{-1 }}$ ) was less than runoff $\mathrm{P}$ from the NT plots $\left(4.82 \mathrm{mg} \mathrm{L}^{-1}\right)$. Assuming that manure $\mathrm{P}$ availability was similar for both plot types, differences in runoff $\mathrm{P}$ are likely due to less runoff from CT plots $(3.9 \mathrm{~mm})$ compared to NT plots $(8.3 \mathrm{~mm})$ and a lower runoff ratio. Overall, magnitudes of runoff $\mathrm{P}$ concentrations in the first events after the January application were similar to the other two manure applications on top of snow (January 2016 and December 2016).

The above presentation of dissolved runoff $\mathrm{P}$ data highlights how hydrology (specifically the runoff ratio) can influence manure runoff $\mathrm{P}$ concentrations. To investigate this, we compared hydrology and runoff $\mathrm{P}$ data pairs, where a pair consisted of runoff events on the same date for both $\mathrm{CT}$ and NT plots that had manure applied at the same time. For example, one pair was for the February 20, 2016 event from both CT and NT plots following the January application. There were eight such data pairs across the two winters. For each pair, we calculated the runoff ratio for both 
293 CT and NT plots, and then divided the lesser ratio by the greater ratio (CT plots had a lesser ratio 294 in all but one event). We then divided the runoff $\mathrm{P}$ concentration from the corresponding lesser 295 ratio by the runoff $\mathrm{P}$ concentration of the greater ratio. We then plotted these relative runoff ratios 296 and the relative runoff $\mathrm{P}$ concentrations for all eight data pairs. For resulting data in Fig. 4, there 297 was a good correlation showing that relative runoff $\mathrm{P}$ increased as relative runoff ratios increased.

298 This is because more rain+snowmelt water is moving in runoff rather than infiltrating into soil and 299 carrying P mobilized from manure in runoff. Because the relationship was consistent across a 300 number of runoff events at different times after manure application, hydrology likely has a greater 301 influence on manure P runoff concentrations than timing of runoff relative to manure application 302 (Vadas et al., 2011).

\section{SurPhos Simulations}

We have proposed that the runoff dissolved $\mathrm{P}$ dynamics described above are largely the result of three drivers, which are i) manure $\mathrm{P}$ availability, as represented by both initial $\mathrm{P}$ content 307 of applied manure and if liquid manure is applied onto snow, ii) how much P is mobilized out of 308 manure by rain and snowmelt water, and iii) the hydrology of the runoff event as represented by the runoff ratio. To explore the validity of our proposed mechanisms, we simulated our experimental conditions with the SurPhos since the model simulates these processes. Reliably

311 simulating dissolved $\mathrm{P}$ concentrations in runoff for our winter conditions would suggest that the 312 mechanisms in SurPhos (which are consistent with those proposed in our earlier discussion) are 313 the ones controlling manure $\mathrm{P}$ loss in runoff. We note that if liquid manure is applied $(<15 \%$ 314 solids), Surphos assumes $60 \%$ of manure $\mathrm{P}$ infiltrates into soil and is unavailable for direct loss in 
runoff. In this research, we maintained this assumption when liquid manure was applied to bare soil, but eliminated it when manure was applied on top of snow.

Figure 5 shows measured and simulated data for runoff dissolved $\mathrm{P}$ from our field project $(n=39)$. The regression slope relating measured and predicted values was significantly greater than 1.0, but the intercept was not different from $0.0(\mathrm{p}=0.05)$. The NSE was -17.48 , the RMSE was $6.43 \mathrm{mg} \mathrm{L}^{-1}$, and the RSR was 4.24 , which do not suggest reliable P loss predictions. Visual inspection shows five points were highly overpredicted. Four of the points were for the first runoff event after manure application onto snow (1/30/16, 12/25/16, 2/7/17, 2/11/17) and one point was the second event following the $1 / 30 / 16$ event $(2 / 7 / 16)$. SurPhos uses the following equation to estimate WEP release from manure during a rain or snowmelt event:

$$
\mathrm{WEP}_{\mathrm{I}} \text { released }=\left[1.2(\mathrm{~W} /(\mathrm{W}+73.1)]\left(\text { Manure } \mathrm{WEP}_{\mathrm{I}}\right)\right.
$$

where $\mathrm{W}$ is the ratio of water volume (rain and /or snowmelt) to manure mass $\left(\mathrm{cm}^{3} \mathrm{~g}^{-1}\right)$. In lab experiments using the liquid dairy manure from the same source as used in the field study, Vadas et al. (2018) found that Eq. [1] greatly ovepredicted WEP release at lower W values $(<150)$. The $\mathrm{W}$ values for the five events over-predicted ranged from 45 to $148\left(\mathrm{~cm}^{3} \mathrm{~g}^{-1}\right)$. Therefore, we assumed that Eq. [1] was overestimating WEP release from manure and causing overestimations of $\mathrm{P}$ concentrations in runoff. To account for this, we developed the following equation to predict WEP release from the liquid manure used in the field study based on data from Vadas et al. (2018):

$$
\mathrm{WEP}_{\mathrm{I}} \text { release }=\left[0.0000144(\mathrm{~W})^{2.029}\right]\left(\text { Manure } \mathrm{WEP}_{\mathrm{I}}\right)
$$


Using Eq. [2] in the model instead of Eq. [1], the five overpredicted runoff $\mathrm{P}$ points decreased by an average of $14.8 \mathrm{mg} \mathrm{L}^{-1}$ (range in decrease from 3.3 to $33.7 \mathrm{mg} \mathrm{L}^{-1}$ ) while all other prediction points increased by an average of $0.52 \mathrm{mg} \mathrm{L}^{-1}$ (range from decrease of 3.8 to increase of $4.7 \mathrm{mg} \mathrm{L}^{-}$ ${ }^{1}$ ). Compared to Eq. [1], Eq. [2] essentially allowed less manure P release during early runoff events after application, which generally left more $\mathrm{P}$ in manure for release in later events. Overall, new runoff dissolved $\mathrm{P}$ predictions greatly improved (Fig 5). The new regression slope relating measured and predicted values was not significantly different than 1.0, and the intercept was not different from $0.0(\mathrm{p}=0.05)$. The new NSE was 0.55 , the RMSE was $1.00 \mathrm{mg} \mathrm{L}^{-1}$, and the RSR was 0.66. Moriasi et al. (2007) provide guidelines for watershed-scale model performance for monthly time-step data based on NSE and RSR, and would classify our NSE and RSR as satisfactory (NSE $>0.50$ is satisfactory and RSR between 0.60 and 0.70 is satisfactory). In other research evaluating the SurPhos model (Wang et al., 2018; Vadas et al., 2007; Vadas et al., 2017), there has never been a need to use an alternative to Eq. [1], which suggests that use of Eq. [2] was particular to only this liquid manure used in the field study.

Overall, our model performance statistics suggest SurPhos was reliably simulating dissolved $\mathrm{P}$ in runoff from manure for these winter conditions. This in turn suggests that the SurPhos manure $\mathrm{P}$ availability (i.e, liquid manure $\mathrm{P}$ remains completely available in the snowpack when applied on top of snow) and hydrology in (i.e., the amount of rain and snowmelt water available to release WEP from manure and the amount of runoff as represented by the runoff ratio) processes are indeed the ones that control manure dissolved P loss in runoff. From a management and policy perspective, this means that dissolved $\mathrm{P}$ loss from manure applied in winter is a function of seasonal hydrology conditions and not the month that manure was applied. For example, manure applied in December may have as much risk of P loss in runoff as manure applied in February if 
361 the runoff hydrology is similar. Using the SurPhos model, Vadas et al. (2017) explored the longterm risk of dissolved P loss from manure applied during different days of the year. Similarly, Fallow et al. (2007), proposed a risk assessment approach based on soil and snow cover conditions to find suitable days for winter manure application. From a policy perspective, combining these modeling approaches could be used to set guidelines about the dynamics of P loss risk from manure spreading in winter and what fall or spring time periods are most suitable for application. However from a management perspective, our research suggests that producers should still plan on assessing specific snow and soil conditions at the time of manure application during the winter in addition to following guidelines about the risk of $\mathrm{P}$ loss in any given winter month.

\section{Summary}

Winter and early spring is consistently a time when significant runoff occurs from agricultural fields due to rain and snowmelt events on frozen soils. Therefore, winter application of dairy manure can greatly increase the risk of $\mathrm{P}$ loss in that runoff relative to other times of the year. Understanding the hydrologic and soil frost conditions that control winter manure P loss can help develop management guidelines or application policies that can consistently reduce P runoff. Our results from winter runoff monitoring over two years show that weather, soil frost conditions, and runoff timing and hydrology can vary greatly. However, there were consistent processes that controlled manure dissolved $\mathrm{P}$ runoff. For example, if liquid dairy manure can be applied onto bare, unfrozen soil, the manure liquid will have a chance to infiltrate into soil and reduce $\mathrm{P}$ available for loss in runoff. Liquid manure application on top of snow allows manure liquid to remain in the snowpack and increase $\mathrm{P}$ available to runoff. When runoff does occur, it is the runoff hydrology (as represented by both the amount of water available to release $\mathrm{P}$ from manure and the 
runoff ratio) that will control manure $\mathrm{P}$ concentrations in runoff. Therefore, management practices that can increase winter water infiltration can help reduce both runoff $\mathrm{P}$ concentrations and loads. We observed that fall tillage helped to create surface roughness that increased water infiltration into soil and decrease runoff $\mathrm{P}$ concentrations. However, such tillage to increase winter water infiltration would have to be balanced with practices that help decrease soil erosion in other parts of the year that might occur due to fall soil disturbance. Our results also show that timing of manure application is not a reliable practice for reducing manure $\mathrm{P}$ in runoff. For example, risk of $\mathrm{P}$ loss in the first runoff events after a December manure application on top of snow can be just as high as that from a similar January or February application. Therefore, if winter manure applications need to occur, they should be before snow cover or significant soil frost develops and onto a rough soil surface that can promote depressional water storage and infiltration. Finally, the SurPhos model is a tool that can be reliably used to explore and guide realistic expectations of the extent of P loss for different management and policy scenarios.

\section{References}

Baker, D.B., R. Confesor, D.E. Ewing, L.T. Johnson, J.W. Kramer, and B.J. Merryfield. 2014. Phosphorus loading to Lake Erie from the Maumee, Sandusky and Cuyahoga rivers: The importance of bioavailability. J Great Lakes Res 40:502-517.

Bennett, N.D., B.F.W. Croke, G. Guariso, J.H.A. Guillaume, S.H. Hamilton, A.J. Jakeman, S. Marsili-Libelli, L.T.H. Newham, J.P. Norton, C. Perrin, S.A. Pierce, B. Robson, R. Seppelt, A.A. Voinov, B.D. Fath, and V. Andreassian. 2013. Characterising performance of environmental models. Environ Modell Softw 40:1-20.

Bolster, C.H., and P.A. Vadas. 2013. Sensitivity and Uncertainty Analysis for the Annual Phosphorus Loss Estimator Model. J. Environ. Qual. 42:1109-1118.

Bonilla, C.A., D.G. Kroll, J.M. Norman, D.C. Yoder, C.C. Molling, P.S. Miller, J.C. Panuska, J.B. Topel, P.L. Wakeman, and K.G. Karthikeyan. 2006. Instrumentation for measuring runoff, sediment, and chemical losses from agricultural fields. J. Environ. Qual. 35:216223.

Collick, A.S., T.L. Veith, D.R. Fuka, P.J.A. Kleinman, A.R. Buda, J.L. Weld, R.B. Bryant, P.A. Vadas, M.J. White, R.D. Harmel, and Z.M. Easton. 2016. Improved Simulation of Edaphic and Manure Phosphorus Loss in SWAT. J. Environ. Qual. 45:1215-1225. 
Converse, J.C., G.D. Bubenzer, and W.H. Paulson. 1976. Nutrient Losses in Surface Runoff from Winter Spread Manure. Trans. ASAE 19:517-519.

Fallow, D.J., D.M. Brown, J.D. Lauzon, and G.W. Parkin. 2007. Risk assessment of unsuitable winter conditions for manure and nutrient application across Ontario. J. Environ. Qual. 36:31-43.

Good, L.W., P. Vadas, J.C. Panuska, C.A. Bonilla, and W.E. Jokela. 2012. Testing the Wisconsin Phosphorus Index with Year-Round, Field-Scale Runoff Monitoring. J. Environ. Qual. 41:1730-1740.

Hansen, N.C., S.C. Gupta, and J.F. Moncrief. 2000. Snowmelt runoff, sediment, and phosphorus losses under three different tillage systems. Soil Till Res 57:93-100.

Klausner, S.D., P.J. Zwerman, and D.F. Ellis. 1976. Nitrogen and Phosphorus Losses from Winter Disposal of Dairy Manure. J. Environ. Qual. 5:47-49.

Kleinman, P.J.A., A.M. Wolf, A.N. Sharpley, D.B. Beegle, and L.S. Saporito. 2005. Survey of water-extractable phosphorus in livestock manures. Soil Sci. Soc. Am. J. 69:701-708.

Komiskey, M.J., T.D. Stuntebeck, D.R. Frame, and F.W. Madison. 2011. Nutrients and sediment in frozen-ground runoff from no-till fields receiving liquid-dairy and solid-beef manures. J. Soil Water Conserv. 66:303-312.

Kongoli, C.E., and W.L. Bland. 2002. Influence of manure application on surface energy and snow cover: Field experiments. J. Environ. Qual. 31:1166-1173.

Lewis, T.W., and J.C. Makarewicz. 2009. Winter application of manure on an agricultural watershed and its impact on downstream nutrient fluxes. J Great Lakes Res 35:43-49.

Liu, J., P.J.A. Kleinman, H. Aronsson, D. Flaten, R.W. McDowell, M. Bechmann, D.B. Beegle, T.P. Robinson, R.B. Bryant, H.B. Liu, A.N. Sharpley, and T.L. Veith. 2018. A review of regulations and guidelines related to winter manure application. Ambio 47:657-670.

Liu, J., T.L. Veith, A.S. Collick, P.J.A. Kleinman, D.B. Beegle, and R.B. Bryant. 2017. Seasonal Manure Application Timing and Storage Effects on Field-and Watershed-Level Phosphorus Losses. J. Environ. Qual. 46:1403-1412.

Moriasi, D.N., J.G. Arnold, M.W. Van Liew, R.L. Bingner, R.D. Harmel, and T.L. Veith. 2007. Model evaluation guidelines for systematic quantification of accuracy in watershed simulations. Trans. ASABE 50:885-900.

Murphy, J., and J.P. Riley. 1962. A Modified Single Solution Method for Determination of Phosphate in Natural Waters. Anal. Chim. Acta 27:31-36.

Owens, L.B., J.V. Bonta, M.J. Shipitalo, and S. Rogers. 2011. Effects of Winter Manure Application in Ohio on the Quality of Surface Runoff. J. Environ. Qual. 40:153-165.

Parris, K. 2011. Impact of Agriculture on Water Pollution in OECD Countries: Recent Trends and Future Prospects. Int J Water Resour D 27:33-52.

Phillips, P.A., J.L.B. Culley, F.R. Hore, and N.K. Patni. 1981. Pollution Potential and Corn Yields from Selected Rates and Timing of Liquid Manure Applications. Trans. ASAE 24:139-144.

Sedorovich, D.M., C.A. Rotz, P.A. Vadas, and R.D. Harmel. 2007. Simulating management effects on phosphorus loss from farming systems. Trans. ASABE 50:1443-1453.

Sharpley, A. 2016. Managing agricultural phosphorus to minimize water quality impacts. Scientia Agricola 73:1-8.

Singh, S., N. Brandenburg, L. Ahiablame, A. Gonzalez, J. Kjaersgaard, T.P. Trooien, and S. Kumar. 2017. Response of winter manure application on surface runoff water quantity and quality from small watersheds in South Dakota. Water Air Soil Poll. 228. 
Srinivasan, M.S., R.B. Bryant, M.P. Callahan, and J.L. Weld. 2006. Manure management and nutrient loss under winter conditions: A literature review. J. Soil Water Conserv. 61:200209.

Steenhuis, T.S., G.D. Bubenzer, J.C. Converse, and M.F. Walter. 1981. Winter-Spread Manure Nitrogen Loss. Trans. ASAE 24:436-442.

Stock, M.N., F.J. Arriaga, P.V. Vadas, and K.G. Karthikeyan. 2019. Manure application timing drives energy absorption for snowmelt on an agricultural soil. J. Hydrology. 569:51-60.

Ulen, B. 2003. Concentrations and transport of different forms of phosphorus during snowmelt runoff from an illite clay soil. Hydrological Processes 17:747-758.

USDA-NRCS. 2004. NRCS National Engineering Handbook - Part 630/Hydrology. Chapter 11. Snowmelt.

Vadas, P.A. 2006. Distribution of phosphorus in manure slurry and its infiltration after application to soils. J. Environ. Qual. 35:542-547.

Vadas, P.A., W.J. Gburek, A.N. Sharpley, P.J.A. Kleinman, P.A. Moore, M.L. Cabrera, and R.D. Harmel. 2007. A model for phosphorus transformation and runoff loss for surface-applied manures. J. Environ. Qual. 36:324-332.

Vadas, P.A., L.W. Good, W.E. Jokela, K.G. Karthikeyan, F.J. Arriaga, and M. Stock. 2017. Quantifying the impact of seasonal and short-term manure application decisions on phosphorus loss in surface runoff. J. Envrion. Qual. 46:doi:10.2134/jeq2016.2106.0220.

Vadas, P.A., W.E. Jokela, D.H. Franklin, and D.M. Endale. 2011. The Effect of Rain and Runoff When Assessing Timing of Manure Application and Dissolved Phosphorus Loss in Runoff. J. Am. Water Resour. Assoc. 47:877-886.

Vadas, P.A., and J.M. Powell. 2013. Monitoring nutrient loss in runoff from dairy cattle lots. Agric. Ecosys. Environ. 181:127-133.

Vadas, P.A., M.N. Stock, G.W. Feyereisen, F.J. Arriaga, L.W. Good, and K.G. Karthikeyan. 2018. Temperature and Manure Placement in a Snowpack Affect Nutrient Release from Dairy Manure during Snowmelt. J. Environ. Qual. 47:848-855.

Wang, Z.Z., T.Q. Zhang, C.S. Tan, P. Vadas, Z.M. Qi, and C. Wellen. 2018. Modeling phosphorus losses from soils amended with cattle manures and chemical fertilizers. Sci. Total. Environ. 639:580-587.

Williams, M.R., G.W. Feyereisen, D.B. Beegle, and R.D. Shannon. 2012a. Soil Temperature Regulates Nitrogen Loss from Lysimeters Following Fall and Winter Manure Application. Trans. ASABE 55:861-870.

Williams, M.R., G.W. Feyereisen, D.B. Beegle, and R.D. Shannon. 2012b. Soil Temperature Regulates Phosphorus Loss from Lysimeters Following Fall and Winter Manure Application. Trans. ASABE 55:871-880.

Williams, M.R., G.W. Feyereisen, D.B. Beegle, R.D. Shannon, G.J. Folmar, and R.B. Bryant. 2011. Manure application under winter conditions: Nutrient runoff and leaching losses. Trans. ASABE 54:891-899.

Young, R.A., and R.F. Holt. 1977. Winter-Applied Manure - Effects on Annual Runoff, Erosion, and Nutrient Movement. J. Soil Water Conserv. 32:219-222.

Young, R.A., and C.K. Mutchler. 1976. Pollution Potential of Manure Spread on Frozen Ground. J. Environ. Qual. 5:174-179. 
Figure Captions:

508

509 Figure 1. Air temperature (a), precipitation (rain and snow, b), estimated amount of water from

510 rain + snowmelt (c), and runoff (d) from CT and NT plots during the 2015-2016 winter

511 monitoring period.

512

513 Figure 2. Air temperature (a), precipitation (rain and snow, b), estimated amount of water from 514 rain + snowmelt (c), and runoff (d) from CT and NT plots during the 2016-2017 winter 515 monitoring period.

516

Figure 3. Dissolved P concentrations in runoff from CT and NT plots receiving liquid dairy manure in either December (Dec) or January (Jan) during both the 2015-2016 and 2016-2017

519 winter monitoring periods. Vertical lines indicates dates of manure application.

Figure 4. Data from seven events after manure application when runoff occurred from both CT and NT plots. Regression lines show the relationship between relative runoff nutrient concentration and relative runoff ratios for the events.

Figure 5. Measured and SurPhos simulated dissolved P concentrations in runoff for the field runoff data. Data represent model results for both the original SurPhos Eq. [1] for manure P release during snowmelt, and an adapted Eq. [2] particular to the dairy manure used in the field study. 
530 Table 1. Date, hydrologic conditions, and precipitation, snowmelt, and runoff for CT and NT plots 531 during 2015-2016 and 2016-2017 winter monitoring periods. Runoff ratios referred to in the text 532 are calculated by dividing runoff amounts for a given event by the rain+snowmelt water amounts 533 for the same event.

\begin{tabular}{|c|c|c|c|c|c|c|}
\hline \multirow[b]{3}{*}{ Date } & \multirow{3}{*}{ Condition } & \multirow{3}{*}{$\begin{array}{c}\text { Rain }+ \\
\text { Snowmelt } \\
(\mathrm{mm})\end{array}$} & \multicolumn{4}{|c|}{ Runoff (mm) } \\
\hline & & & \multicolumn{2}{|c|}{$\mathrm{CT}$} & \multicolumn{2}{|c|}{ No-Till } \\
\hline & & & December & January & December & January \\
\hline $12 / 13 / 15$ & Rain & $49.6(0.0)$ & -- & -- & 1.4 & 1.7 \\
\hline 1/8/16 & Rain on Snow & $4.9(3.4)$ & -- & -- & 3.1 & 4.2 \\
\hline $1 / 30 / 16$ & Snowmelt & $10.1(5.4)$ & -- & -- & -- & 1.9 \\
\hline $2 / 7 / 16$ & Rain on Snow & $4.5(0.2)$ & -- & -- & -- & 1.6 \\
\hline $2 / 18 / 16$ & Snowmelt & $43.2(15.9)$ & 3.2 & 4.7 & 41.9 & 38.6 \\
\hline $3 / 15 / 16$ & Rain & $32.8(0.0)$ & -- & -- & 11.0 & 5.9 \\
\hline $3 / 30 / 16$ & Rain & $26.8(0.0)$ & -- & -- & 3.4 & 1.4 \\
\hline $12 / 25 / 16$ & Rain on Snow & $29.6(5.7)$ & -- & -- & 0.4 & 0.5 \\
\hline $1 / 10 / 17$ & Rain on Snow & $14.9(3.7)$ & 0.4 & 0.3 & 8.4 & 11.5 \\
\hline $1 / 18 / 17$ & Rain on Snow & $23.8(4.2)$ & 7.5 & 20.9 & 10.3 & 5.4 \\
\hline $1 / 20 / 17$ & Rain on Snow & $24.7(5.7)$ & 8.8 & 12.9 & 23.4 & 8.4 \\
\hline $2 / 7 / 17$ & Snowmelt & $13.8(2.1)$ & -- & -- & 4.3 & 1.6 \\
\hline $2 / 11 / 17$ & Snowmelt & $28.9(8.3)$ & 9.2 & 3.9 & 4.1 & 8.4 \\
\hline $2 / 16 / 17$ & Snowmelt & $12.7(7.2)$ & -- & -- & 0.4 & - \\
\hline $2 / 20 / 17$ & Rain & $30.0(5.2)$ & -- & -- & 0.3 & 0.3 \\
\hline $2 / 28 / 17$ & Rain & $29.4(0.0)$ & -- & -- & 0.3 & 0.6 \\
\hline
\end{tabular}

534 

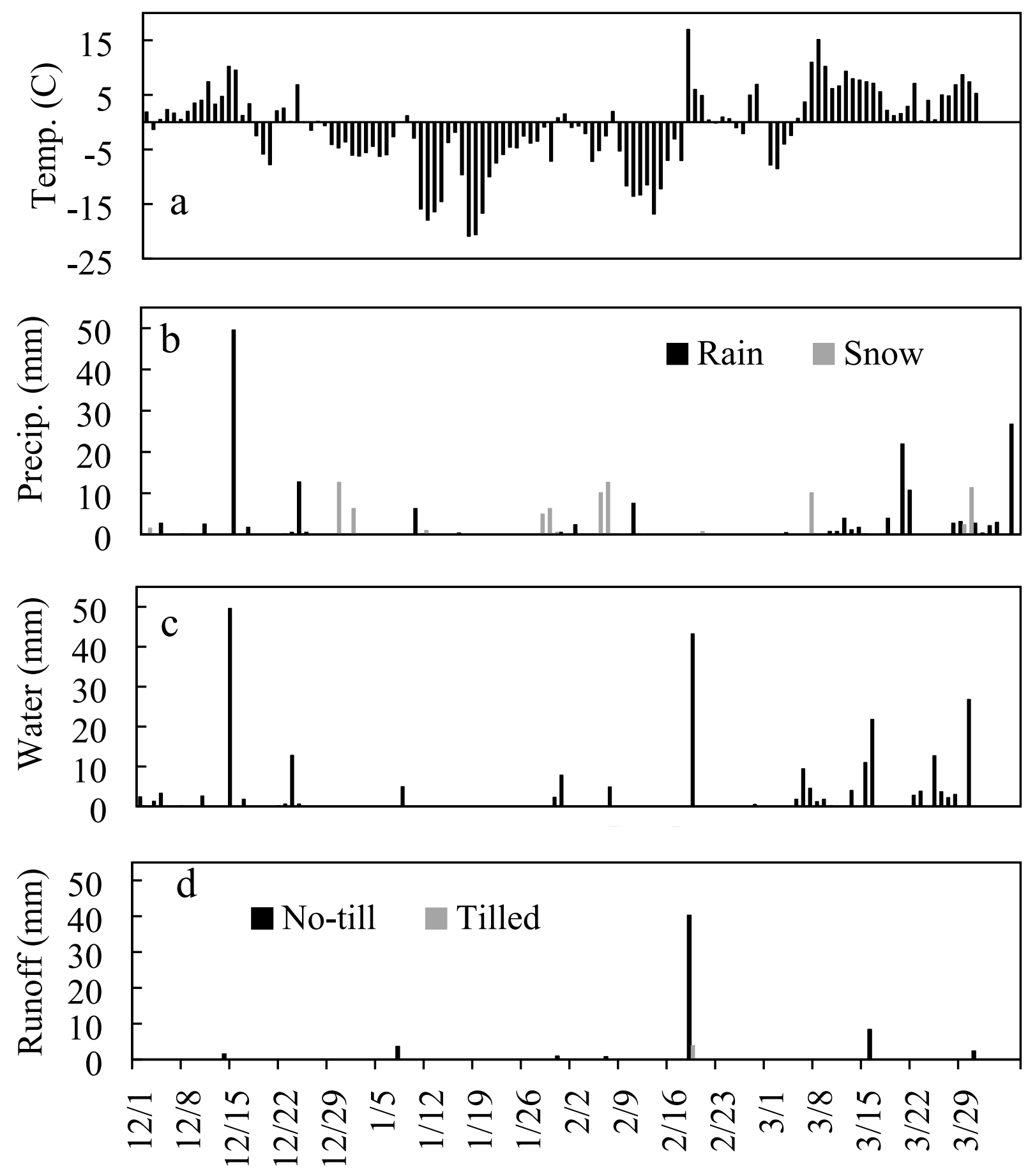

Fig. 1. 2015-2016 

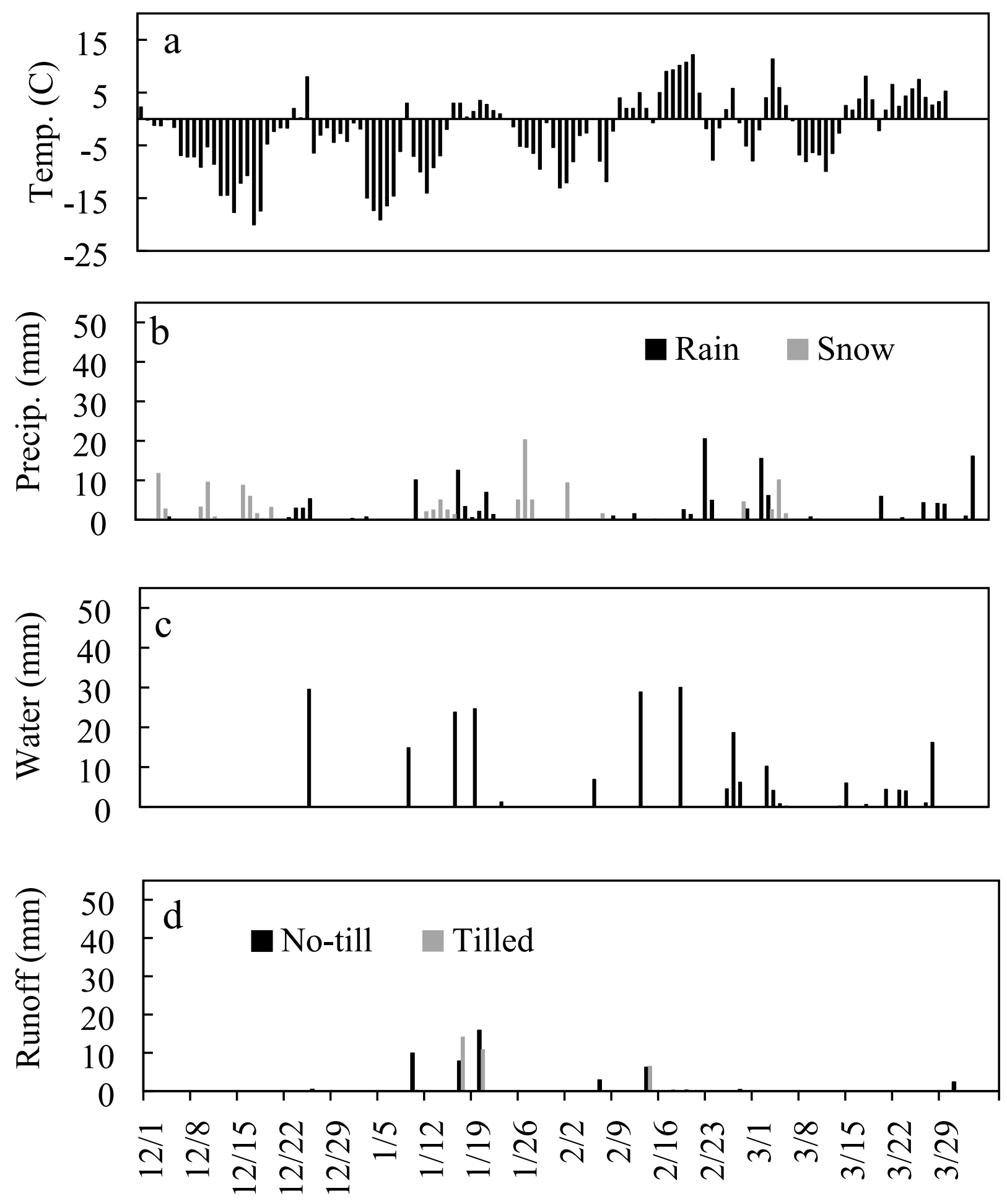

Fig. 2. 2016-2017 
Figure 3
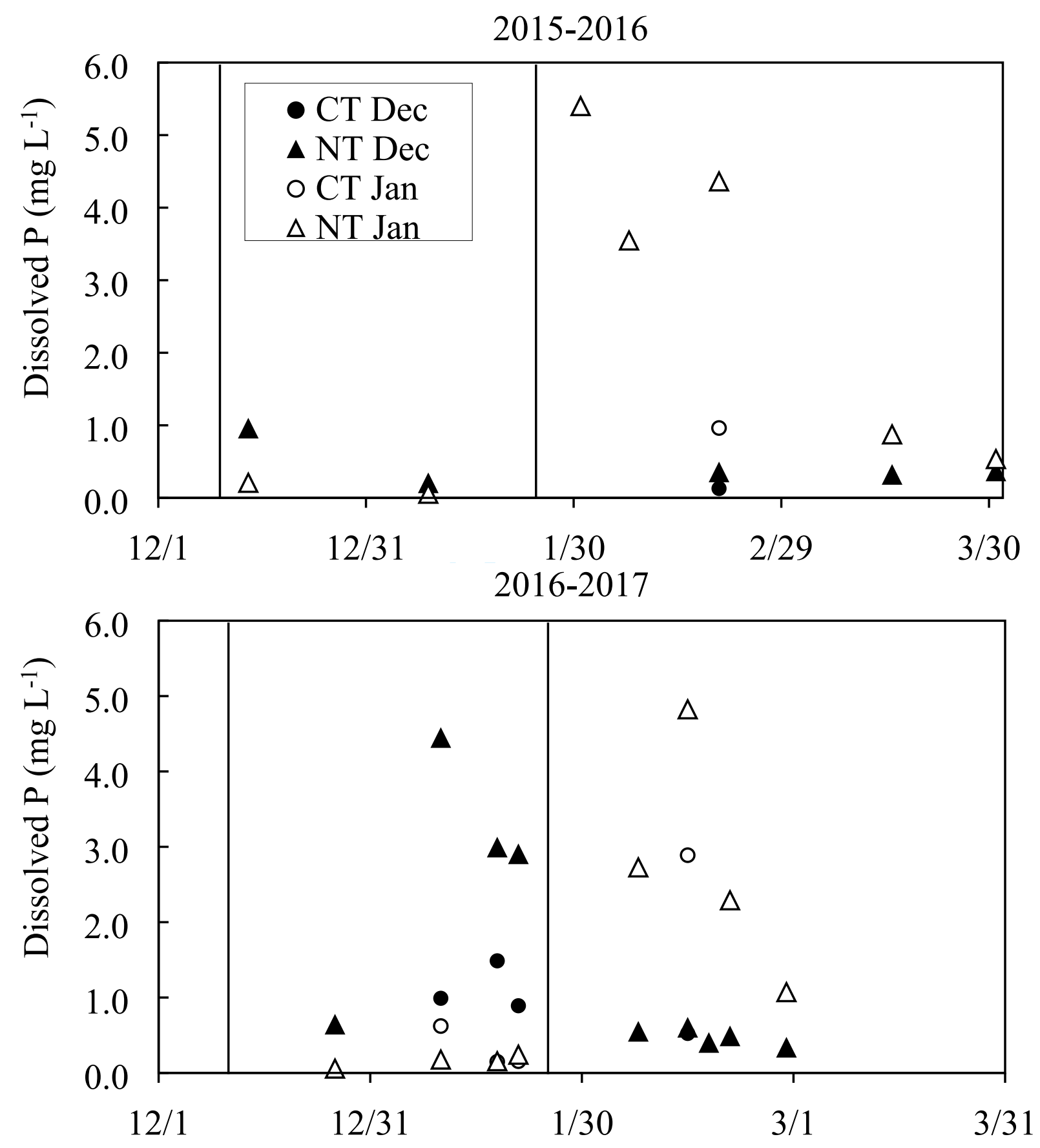
Figure 4

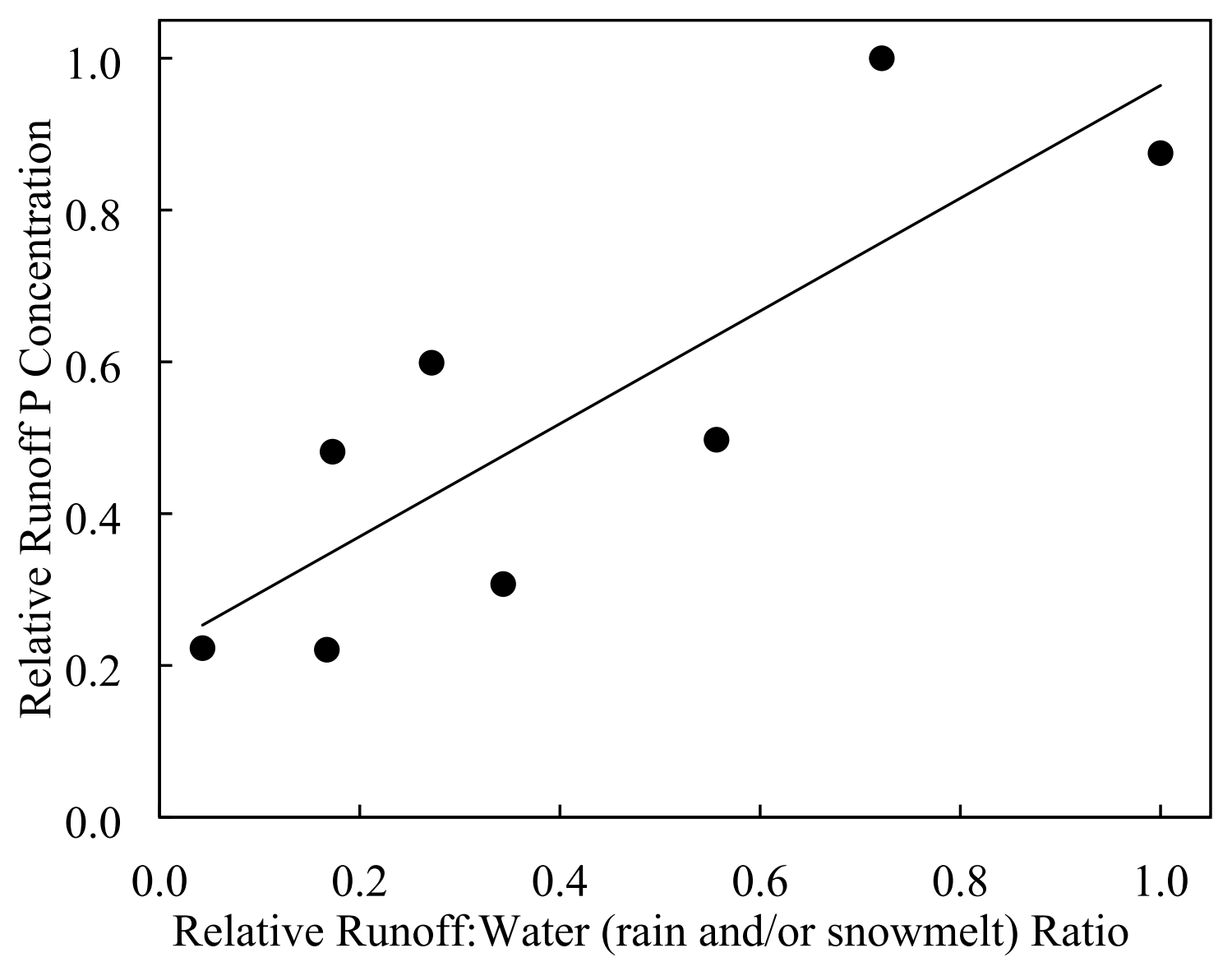


Figure 5

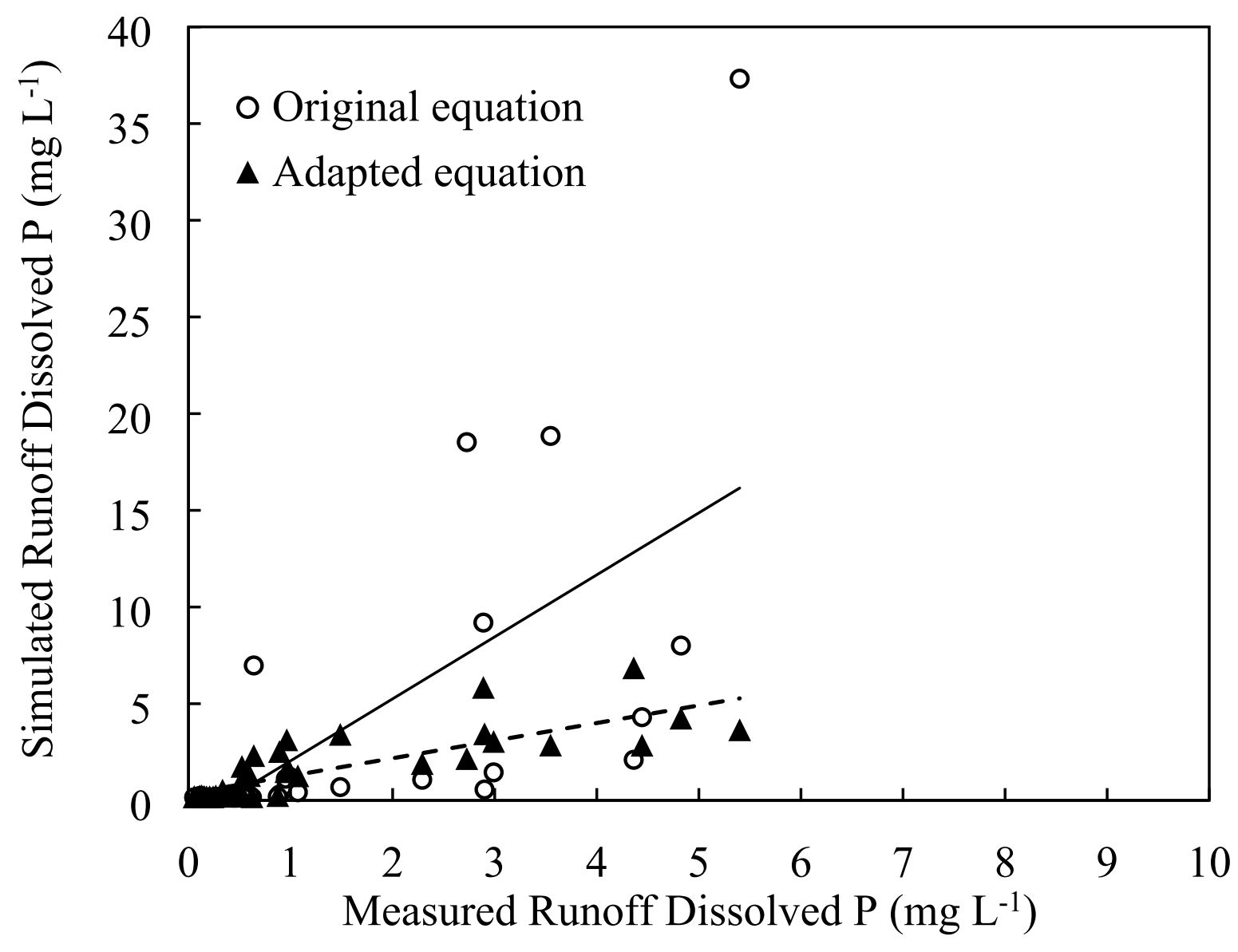

